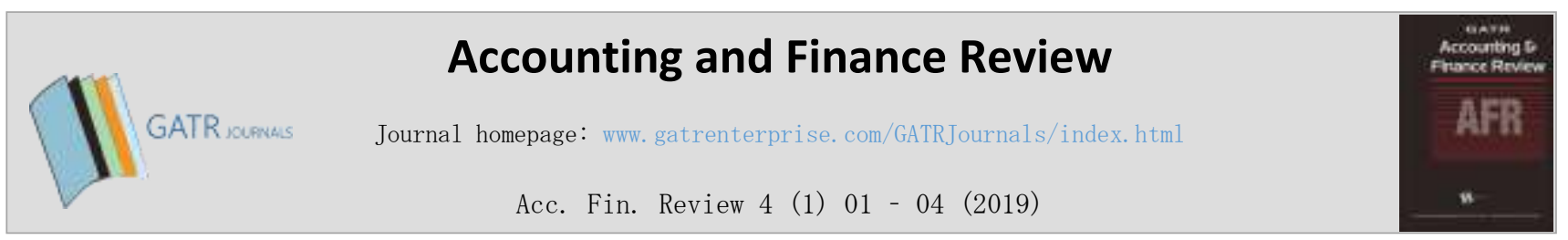

\title{
The Effect of Corporate Tax Planning On Firm Value
}

\author{
Silvy Christina ${ }^{1}$
}

Trisakti School of Management, Kyai tapa No. 20, 11440, Jakarta, Indonesia

\begin{abstract}
Objective - This research aims to empirically examine the effect of tax planning on firm value. The population of this research consists of manufacturing companies listed on the Indonesian Stock Exchange (IDX) from 2014 to 2016.

Methodology/Technique - This research uses 3 recent years and uses variables not used in previous research. The 43 respondents were chosen using purposive sampling. The hypotheses were tested using multiple regressions with Eviews program to determine the relationship between each independent variable to firm value.

Findings - The empirical results show that tax planning that is measured by the cash effective tax rate has a negative effect on firm value, while tax planning measured by effective cash rate and tax savings has no effect on firm value.

Novelty - The study recommends the need for firms to institute more robust tax planning practices that will help reduce their effective tax liabilities and therefore improve their overall value. Firms that engage in better tax planning practices are likely to get higher firm value.
\end{abstract}

Type of Paper: Empirical.

JEL Classification: M40, M42, M49.

Keywords: Firm Performance; Tax Planning; Effective Tax Rate; Cash Effective Tax Rate; Tax Saving.

\section{Introduction}

Corporate tax managers have a responsibility to minimize company tax liability. A firm's tax liability has an impact on their profitability. This means that to increase a company's profitability will create difficulty in lowering their tax liabilities (Oyemimi \& Onakoya, 2016). According to Nike et. al. (2014), there are several ways to reduce tax liability, including: tax planning, tax avoidance, and tax evasion. Tax planning and tax avoidance are safer options, as neither contravene applicable tax regulations. On the other hand, tax evasion expressly contravenes those laws. According to Suandy (2011), tax planning refers to the effort made to save and minimize tax payments, without violating the tax regulation. In addition, tax planning can be used to increase firm value because it increases shareholder wealth. Nike et. al. (2014), Wahab and Holland (2012), Winanto and Utoyo (2013) all state that tax planning does not affect firm performance, because tax planning activities are considered as earnings management practices.

\footnotetext{
* Paper info: Revised: December 10, 2018

Accepted: March 19, 2019

* Corresponding author: Silvy Christina

E-mail: silvy@stietrisakti.ac.id

Affiliation: Trisakti School of Management, Kyai tapa No. 20, 11440, Jakarta, Indonesia
} 
However, according to Fajrin et. al. (2018), Oyeyemi and Babatunde (2016), Zemzem and Ftouhi (2016), and Zemzem and Ftouhi (2013), tax planning has a negative effect on firm value.

This means that smaller tax payments will increase the firm value. Due to these inconsistent results, investors are now concerned with the amount of money they should be investing in certain companies. In order to attract investors, companies should try to increase the firm's value. One way of achieveing this is through tax planning. This phenomenon is the basis of the present research.

\section{Literature Review}

\subsection{Agency Theory}

In agency theory, the parties involved include the manager (agents) and investors (principals). More often that not, principals and agents in an agency relationship have differing interests; this is a source of distrust between those parties. Jensen and Meckling (1976) state that the separation between the owners and managers may give rise to agency problems, such as moral hazards and adverse selection. Jensen and Meckling (1976) also state that agency costs may reduce agency problems, such as: (1) monitoring expenditures, (2) bonding expenditures, and (3) residual loss.

\subsection{Tax Planning}

Hoffman (1961) states that tax planning refers to the process whereby firms identify legal methods to reduce their tax liability by capitalizing on technical loopholes in tax regulations. Due to the sophisticated nature of the tax process and structures, the loopholes in tax regulations enable taxpayers gain certain tax benefits. Companies aim to reduce their income tax to minimize the effect it has on their income and hence their overall value. Tax planning should be flexible and must be able to accommodate changes in applicable tax laws and can be personalized according to the needs of the company.

\subsection{Tax Planning and Firm Value}

According to Pohan (2013), tax planning refers to the process of organizing personal and corporate taxpayer businesses by making use of loopholes in applicable taxation regulations. According to Zemzem and Ftouhi (2016), Oyeyemi and Babatunde (2016), Zemzem and Ftouhi (2013), and Fajrin et. al. (2018), tax planning has a negative effect on firm value. This means that the smaller the tax payment a company is required to make, the higher the firm's value will be. This is because money that is not being spent on corporate taxes is being used within the company and the increase in firm value will necessarily attract investors, who also add value to the company. Based on the explanation above, the following hypothesis is proposed:

H1: Tax planning has a negative affect on firm value.

\section{Research Methodology}

The population used in this research includes manufacturing companies listed on the Indonesian Stock Exchange between 2014 and 2016. The sample was selected using purposive sampling, resulting in 43 companies. To test the hypothesis, multiple regression is used.

\subsection{Definition Operation}


Firm value in this research is measured using return on assets. Tax planning in this research is measured using the effective tax rate, cash effective tax rate and tax savings. Effective tax rate is measured by income tax expenses divided by income before tax. Cash effective tax rate is measured by tax paid by companies divided income before tax. Tax saving is the difference between the statutory tax rate and the effective tax rate. In this research, firm size is measured using a logarithm of natural total asset and the current ratio is measured using current assets divided by current liabilities.

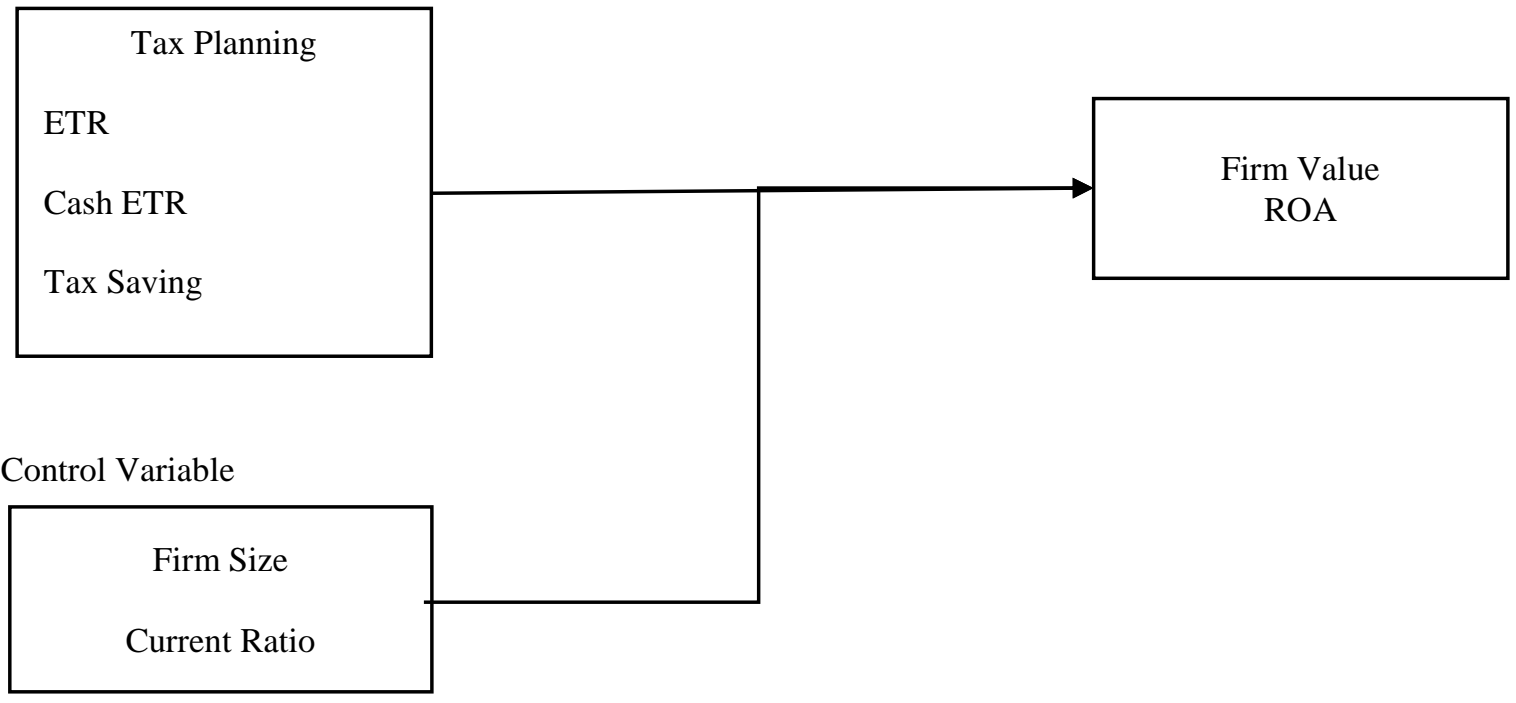

Figure 1. Research Framework

\section{Results}

The result of descriptive statistic and hypothesis result are show in Table 1 and Table 2 below.

Table 1. Descriptive Statistics

\begin{tabular}{llllll}
\hline & $\mathrm{N}$ & Minimum & Maximum & Mean & Std. Deviation \\
\hline ROA & 129 & 0,0000665 & 2,988333 & 0,118208 & 0,266681 \\
ETR & 129 & 0,001470 & 0,961134 & 0,262771 & 0,118500 \\
CETR & 129 & 0,029948 & 0,881081 & 0,029948 & 0,135603 \\
TS & 129 & $-0,711134$ & 0,029948 & 0,295502 & 0,118500 \\
SIZE & 129 & 25,61948 & 33,19881 & 28,59047 & 1,772932 \\
CR & 129 & 0,450341 & 13,35001 & 2,653766 & 2,013086 \\
\hline
\end{tabular}

Table 2. Hypothesis Results

\begin{tabular}{|l|l|l|l|}
\hline & Model 1 & Model 2 & Model 3 \\
\hline C & 0,826754 & 1,267705 & 0,773456 \\
\hline ETR & $-0,675138$ & - & - \\
\hline CETR & - & $-2,967790^{*}$ & - \\
\hline
\end{tabular}




\begin{tabular}{|l|l|l|l|}
\hline FS & - & - & 0,675138 \\
\hline SIZE & $-0,499332$ & $-0,774175$ & $-0,499332$ \\
\hline CR & 0,120821 & $-0,011724$ & 0,120821 \\
\hline
\end{tabular}

\section{Discussion}

From Table 2 above, it can be seen that tax planning is measured by cash the effective tax rate and has an effect on firm value, whereas the other measures of tax planning do not have an effect on firm value. This result shows that tax planning has a negative effect on firm value. This means that if a company implements effective tax planning procedures, this will increase the value of the firm, reducing their tax payments and increasing overall capital. Contrary to this, when a company does not have effective tax planning procedures in place, the value of the firm is likely to decrease. These results are supported by Zemzem and Ftouhi (2016), Oyeyemi and Babatunde (2016), Zemzem and Ftouhi (2013), and Fajrin et. al. (2018).

\section{Conclusion}

The purpose of this research is to obtain empirical evidence on the effect of corporate governance and tax planning on firm value. The results show that tax planning has a negative effect on firm value, which is consistent with the findings of Zemzem and Ftouhi (2016), Oyeyemi and Babatunde (2016), Zemzem and Ftouhi (2013), and Fajrin et. al. (2018). When a company implements effective tax planning, this will increase the firm's value. Their tax payments will reduce and their profits will increase, thereby attracting further investments by outside investors. On the other hand, when a company does not have effective tax planning procedures in place, the value of the firm will likely decrease.

\section{References}

Fajrin, A., Diana, N. and Mawardi, M. C. (2018). The Effect of Tax Planning On Company Value With Company Transparency As A Moderation Variable (Study on Manufacturing Companies on the Indonesia Stock Exchange Period 2013-2016). Journal of Accounting Research, 7(2).

Godfrey, J., Hodgson, A., Tarca, A., Hamilton, J. and Holmes, S. (2010). Accounting Theory.

Hoffman, W. H. (1961). The Theory of Tax Planning. The Accounting Review, 36(2), 274.

Jensen, M. C. and Meckling, W. H. (1976). Theory of the Firm: Managerial Behavior, Agency Costs and Ownership Structure. Journal of Financial Economics, 3(4), 305-360.

Nike, Yulisma, Zaitul, Yunilma (2014). The Effect of Tax Planning and Corporate Governance on Firm Value. Journal Fakultas Ekonomi, 4(1).

Oyeyemi, Grace Ogundajo and Babatunde, Onakayo Adegbemi (2016). Tax Planning and Financial Performance of Nigerian Manufacturing Companies. Advance Academic Research Social and Management Sciences. 2(7).

Pohan, Chairil Anwar (2013). Tax Planning “Strategy of Tax Planning and Business". Jakarta: PT Gramedia Pustaka Utama.

Suandy, Erly (2011). Tax Planning. Jakarta: Salemba Empat.

Wahab, N. S. A. and Holland, K. (2012). Tax Planning, Corporate Governance and Equity Value. The British Accounting Review, 44(2), 111-124.

Winanto and Utoyo Widayat (2013). The Effect of Tax Planning and Corporate Governance on Firm Value. Simposium Nasional Akuntansi XVI Manado.

Zemzem, A., \& Ftouhi, K. (2013). Moderating Effects of Board of Directors on the Relationship between Tax Planning and Bank Performance: Evidence from Tunisia. European Journal of Business and Management, 5(32), $148-154$.

Zemzem, A., \& Ftouhi, K. (2016). External corporate governance, tax planning, and firm performance. Corporate Ownership \& Control, 13(3-3), 523-532. 